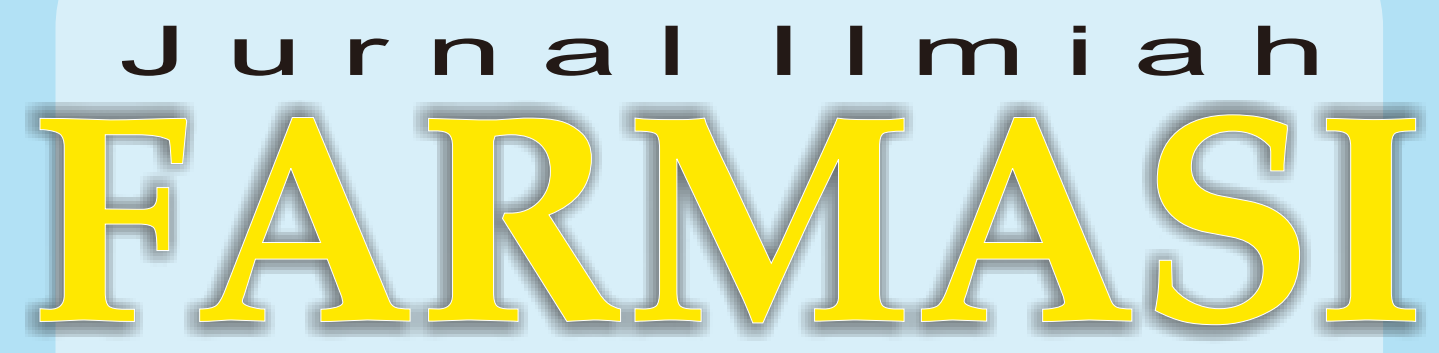

(Scientific Journal of Pharmacy) 
JURNAL ILMIAH FARMASI

(SCIENTIFIC JOURNAL OF PHARMACY)

PIMPINAN UMUM/ PENANGGUNG JAWAB

Dekan Fakultas Matematika dan Ilmu Pengetahuan Alam

Universitas Islam Indonesia

WAKIL PIMPINAN UMUM/ WAKIL PENANGGUNG JAWAB

Ketua Jurusan Farmasi FMIPA UII

\section{MITRA BESTARI}

1. Prof. Dr. Wiryatun Lestariana, Apt

2. Prof. Dr. Zullies Ikawati, Apt

3. Prof. Dr. Sudibyo Martono, Apt

4. Dr. Tedjo Yuwono, Apt

5. Prof. Dr. Dachriyanus, Apt

6. Prof. dr. Iwan Dwiprahasto, MMedSc, PhD

7. Prof. Dr. Lukman Hakim M.Sc., Apt

8. Prof. Dr. Achmad Fudholi, DEA, Apt

9. Prof. Dr. Ibnu Gholib Gandjar, DEA., Apt

\begin{tabular}{ll} 
& \multicolumn{1}{c}{ DEWAN EDITOR } \\
Ketua & : Saepudin, M.Si., Apt \\
Sekretaris & : Rochmy Istikharah, M.Sc., Apt. \\
Anggota & : Vitarani Dwi Ananda Ningrum, M.Si., Apt \\
& Okti R. Mafruhah, MSc., Apt \\
& Dimas Adhi Pradana, MSc., Apt. \\
& Fithria DA. Suryanegara, MSc., Apt. \\
& Ari Wibowo, S.Farm., Apt \\
& Arba Pramudita Ramadani, MSc., Apt. \\
& Oktavia Indrati, S.Farm., Apt.
\end{tabular}

Penerbit

Jurusan Farmasi Fakultas Matematika dan IImu Pengetahuan Alam Universitas Islam Indonesia

Alamat Penerbit Jurusan Farmasi FMIPA UII

Jl. Kaliurang Km. 14,4 Yogyakarta 55584

Telp. (0274) 896439 ext. 3047

Email: jif@uii.ac.id 


\title{
PENGARUH PEMBERIAN SUSU KUDA FERMENTASI TERHADAP ANTIBODI IMUNOGLOBULIN A (IgA) MENCIT SETELAH VAKSINASI HEPATITIS A
}

\author{
Rochmy Istikharah*), Ediati $\left.{ }^{\star \star}\right)$, dan Rumiyati**) \\ *) Jurusan Farmasi Universitas Islam Indonesia Jogjakarta; **) Fakultas Farmasi Universitas \\ Gadjah Mada Jogjakarta
}

\begin{abstract}
IgA-deficient in individuals have developed mucosal infections, atopy, autoimmune diseases and rheumatic. Under the circumstance, the development of an immunomodulator that stimulates immune system, especially $\lg A$, is truly desired. The research is objected on finding out the effect of fermented horse milk treatment on IgA antibody in Hepatitis A immunized mice. IgA concentration in serum and lymphocytes was evaluated using indirect ELISA method. Fermented horse milk group was compared with water group to calculate the percentage of $\operatorname{Ig} A$ concentration increase. Univariate analysis was used to analyze Optical Density (OD) product from ELISA. The result showed that fermented horse milk increased $46.20 \% \lg A$ concentration in serum and $95.47 \%$ in spleen lymphocytes. Univariate analysis showed that fermented horse milk increased significantly $\lg \mathrm{A}$ spleen lymphocytes but not $\lg \mathrm{A}$ serum.
\end{abstract}

Keywords : immunomodulator, IgA, hepatitis A vaccine, ELISA 